\title{
KONDUKTIVITAS PANAS DAN KOEFISIEN PINDAH PANAS PADA PROSES PENGERINGAN GABAH DENGAN MENGGUNAKAN CABINET DRYER
}

\section{HEAT CONDUCTIVITY AND HEAT TRANSFER COEFFICIENT ON GABAH (UNHULLED RICE) DRYING PROCESS USING A DRYER CABINET}

\author{
Riska Rusli1), Jamaluddin²), Subari Yanto ${ }^{3)}$ \\ ${ }^{1}$ Alumni Program Studi Pendidikan Teknologi Pertanian \\ ${ }^{2}$ dan ${ }^{3}$ Dosen PTP FT UNM \\ alifahalgowani@gmail.com
}

\begin{abstract}
ABSTRAK
Tujuan dari penelitian ini adalah untuk mengetahui konduktivitas dan koefisien perpindahan panas pada proses pengeringan gabah dengan menggunakan pengering kabinet. Penelitian ini merupakan jenis penelitian eksperimental yang dilakukan dengan mengeringkan "gabah" dengan variasi suhu $50^{\circ} \mathrm{C}, 60^{\circ} \mathrm{C}$ dan $70^{\circ} \mathrm{C}$ sedangkan durasi pengeringan 160 menit, 170 menit dan 180 menit. Kemudian untuk mengetahui perubahan suhu selama proses pengeringan digunakan termokopel, sedangkan untuk mengetahui perubahan kadar air "gabah" dilakukan dengan uji kadar air sebelum dan sesudah pengeringan dengan menggunakan metode oven. Hasilnya menunjukkan bahwa semakin tinggi suhu pengeringan, suhu "gabah" akan mendekati suhu udara panas, sedangkan kadar air semakin tinggi suhu dan pengeringan dalam waktu lama akan menyebabkan kadar air "gabah" berkurang. Nilai konduktivitas "gabah" dan koefisien perpindahan panas dari "gabah" adalah 0,32 W/m. ${ }^{\circ} \mathrm{C}$ dan $31,77 \mathrm{~W} / \mathrm{m}^{2} .{ }^{\circ} \mathrm{C}$.

Kata Kunci : Gabah, Kadar Air, Koefisien Pindah Panas, Konduktivitas Panas, Pengeringan.
\end{abstract}

\begin{abstract}
The purpose of this research is to know the conductivity and coefficient of heat transfer in drying process of gabah (unhulled rice) by using cabinet dryer. This research is a type of experimental research done by drying "gabah" with temperature variations $50^{\circ} \mathrm{C}, 60^{\circ} \mathrm{C}$ and $70^{\circ} \mathrm{C}$ while the duration of drying 160 minutes, 170 minutes and 180 minutes. then to know the temperature change during the drying process used thermocouple, while to know the change of "gabah" water level is done by water content test before and after drying by using ov en method. The results show that the higher the drying temperature, the "gabah" temperature will be close to the temperature of hot air, while the moisture content the higher the temperature and drying in a long time will cause the "gabah" water content decreases. The value of the "gabah" conductivity and the heat transfer coefficient of the"gabah" is $0.32 \mathrm{~W} / \mathrm{m} .{ }^{\circ} \mathrm{C}$ and $31.77 \mathrm{~W} / \mathrm{m}^{2} .{ }^{\circ} \mathrm{C}$.

Keywords: Unhulled Rice, Water Content, Heat Transfer Coefficient, Thermal Conductivity, Drying.

\section{PENDAHULUAN}

Salah satu proses pasca panen padi yang harus diperhatikan adalah

proses pengeringan, karena pada proses inilah yang menentukan mutu dan kualitas padi atau gabah. Dimana dengan mengeringkan gabah maka
\end{abstract}


kadar air gabah akan berkurang sehingga tidak mudah terserang oleh jamur dan tidak berkecambah selama proses penyimpanan dilakukan.

Masyarakat Indonesia pada umumnya masih banyak menggunakan cara pengeringan konvensional untuk mengeringkan gabah yakni dengan menggunakan sinar matahari langsung dimana cara pengeringan ini sangat tergantung oleh cuaca, membutuhkan waktu yang relatif lama dan tempat penjemuran yang cukup luas padahal seiring dengan berjalannya waktu populasi manusia semakin bertambah yang dimana semakin bertambahnya populasi manusia maka secara otomatis kebutuhan akan makanan maupun tempat tinggal akan semakin bertambah sehingga pengeringan secara konvensional kurang efisien untuk mengeringkan gabah sebagaimana pendapat (Manalu, 2009) yang mengatakan bahwa di Indonesia umumnya masih banyak dijumpai pengeringan padi dengan cara menjemur padi di atas penjemuran yang terbuat dari semen, batu atau tanah. Keuntungan cara ini adalah biaya pengeringan relatif rendah, tidak memerlukan penanganan khusus, hasil pengeringan relatif seragam. Sedangkan kerugiannya adalah sangat tergantung pada cuaca, waktu pengeringan lebih lama, memerlukan areal yang cukup luas untuk penjemuran, jumlah kehilangan lebih banyak.

Berdasarkan permasalahan tersebut maka diperlukan adanya penggunaan alat atau teknologi pada proses pengeringan gabah salah satu contohnya yakni dengan menggunakan alat pengering cabinet dryer. Alat ini merupakan alat pengering bahan pangan yang prinsip kerjanya ialah untuk mengurangi kadar air bahan pangan sebagaimana pendapat (Sumarni, 2010) yang mengatakan bahwa alat pengering cabinet dryer merupakan salah satu alat pengering bahan pangan. Prinsipnya adalah menghilangkan kelembaban bahan menjadi bahan kering. Dimana pada saat penggunaan alat ini maka akan terjadi proses perpindahan panas konduksi dan konveksi.

Perpindahan panas konduksi merupakan perpindahan panas yang terjadi tanpa disertai dengan adanya perpindahan partikel-partikel zat pada saat proses perpindahan panas tersebut terjadi sebagaimana pendapat (Fadly dan Mulfi, 2014) yang mengatakan bahwa perpindahan panas konduks adalah proses perpindahan panas yang mengalir dari benda yang bertemperatur lebih tinggi kebenda yang bertemperatur lebih rendah melalui benda penghubung yang diam (tidak dalam mengalir). Sedangkan konveksi merupakan proses perpindahan panas dari benda yang bertemperatur lebih tinggi kebenda yang bertemperatur lebih rendah melalui benda penghubung,dimana benda penghubung tersebut haruslah memiliki sifat fluida (konduktivitas termal, kalor spesifik dan densitas). Syarat utama mekanisme perpindahan panas konveksi adalah adanya aliran fluida. Perpindahan panas konveksi pada 
pengering terjadi pada fluida kerja yang digunakan (udara) (Fadly dan Mulfi, 2014). Perpindahan panas konduksi memiliki konduktivitas panas dan konveksi memiliki koefisien pindah panas dimana kedua konstanta ini sangat penting untuk diketahui karena dengan diketahuinya hal tersebut maka panas yang akan diberikan pada gabah maupun lama proses pengeringan dapat diatur sesuai dengan kebutuhan energi yang dibutuhkan dalam proses pengeringan gabah.

\section{TUJUAN PENELITIAN}

Penelitian ini bertujuan untuk mengetahui konduktivitas panas dan koefisien pindah panas pada proses pengeringan gaba dengan menggunakan cabinet dryer.

\section{METODE PENELITIAN}

Penelitian ini merupakan penelitian eksperimen yang terdiri atas 2 faktor. Faktor A adalah suhu dengan 3 taraf faktor $\left(50^{\circ} \mathrm{C}, 60^{\circ} \mathrm{C}\right.$ dan $70^{\circ} \mathrm{C}$ ) dan faktor $\mathrm{B}$ adalah lama pengeringan dengan 3 taraf faktor (160 mt, $170 \mathrm{mt}$ dan $180 \mathrm{mt}$ ). Dengan demikian banyaknya perlakuan yang dicobakan sebanyak 9 kombinasi perlakuan dimana setiap perlakuan diulang sebanyak 3 kali.

Alat yang digunakan dalam penelitian ini meliputi Cabinet dryer, Termokopel, Timbangan, Plastik, Toples, Oven dan Desikator.

Bahan yang digunakan dalam penelitian ini adalah gabah basah varietas ciherang. Pengambilan sampel penelitian gabah basah ini dijalan poros malino desa lanna kecamatan parangloe kabupaten gowa sulawesi selatan.

Penelitian dilaksanakan di Laboratorium Program Studi Pendidikan Teknologi Pertanian, Fakultas Teknik, Universitas Negeri Makassar. Waktu pelaksanaan penelitian dimulai pada bulan Desember 2016 sampai dengan Januari 2017.

\section{HASIL DAN PEMBAHASAN}

Profil Suhu Gabah Selama penelitian dilakukan, suhu gabah diukur dengan menggunakan termokopel selama proses pengeringan. Hasil pengukuran suhu dengan menggunakan termokopel dapat dilihat pada Gambar 1, 2 dan 3.

Berdasarkan gambar 1, 2 dan 3 tampak bahwa terjadi peningkatan suhu yang tinggi pada awal proses pengeringan yakni pada lama pengeringan 0-40 mt. Selanjutnya peningkatan suhu gabah cenderung konstan hingga proses pengeringan selesai.

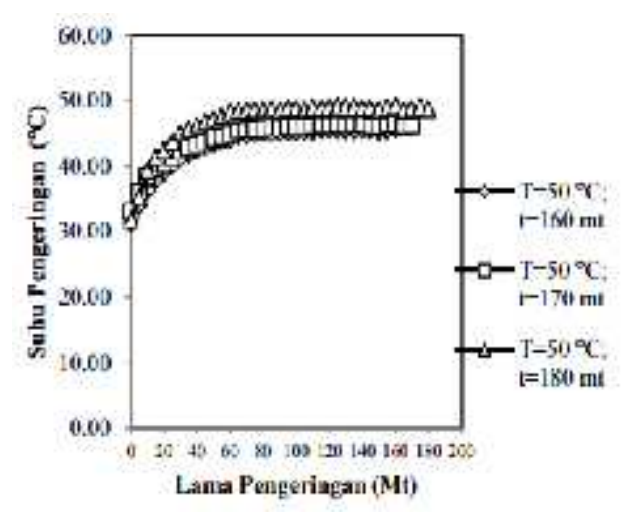

Gambar 1.

Profil suhu gabah selama proses pengeringan pada suhu $50^{\circ} \mathrm{C}$ dengan menggunakan cabinet dryer 


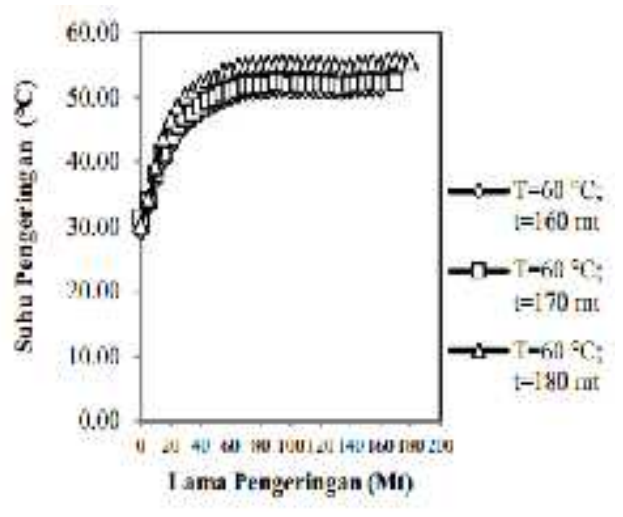

Gambar 2.

Profil suhu gabah selama proses pengeringan pada suhu $60^{\circ} \mathrm{C}$ dengan menggunakan cabinet dryer

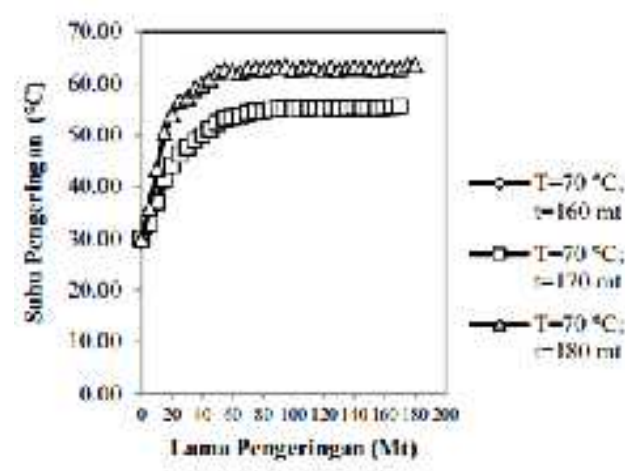

Gambar 3.

Profil suhu gabah selama proses pengeringan pada suhu $70^{\circ} \mathrm{C}$ dengan menggunakan cabinet dryer

Hasil penelitian pengukuran suhu menunjukkan bahwa peningkatan suhu terjadi secara bertahap. Pada awal proses pengeringan terjadi peningkatan suhu yang tinggi karena pada tahap ini terjadi kontak langsung udara panas dengan gabah yang dikeringkan dimana hal ini terjadi karena perbedaan antara suhu gabah dengan udara panas jauh berbeda. Pada proses pengeringan tahap selanjutnya suhu bahan relatif konstan pada waktu pengeringan $40 \mathrm{mt}$ hal ini karena pada waktu tersebut suhu gabah sudah mendekati atau hampir sama dengan suhu udara panas. Hal ini sesuai dengan pendapat (Anton, 2011) yang menyatakan bahwa perbedaan suhu antara media pemanas dan bahan yang makin besar menyebabkan makin cepatnya perpindahan panas ke dalam bahan dan makin cepat pula perpindahan uap air dari bahan ke lingkungan. Dan pendapat (Abdul, 2012) yang menyatakan bahwa semakin besar perbedaan suhu antara medium pemanas dengan bahan pangan makin cepat pemindahan panas ke dalam bahan dan makin cepat pula penghilangan air dari bahan.

\section{Kadar Air Gabah}

Kadar air gabah sebelum dan sesudah pengeringan dapat dilihat pada gambar 4.

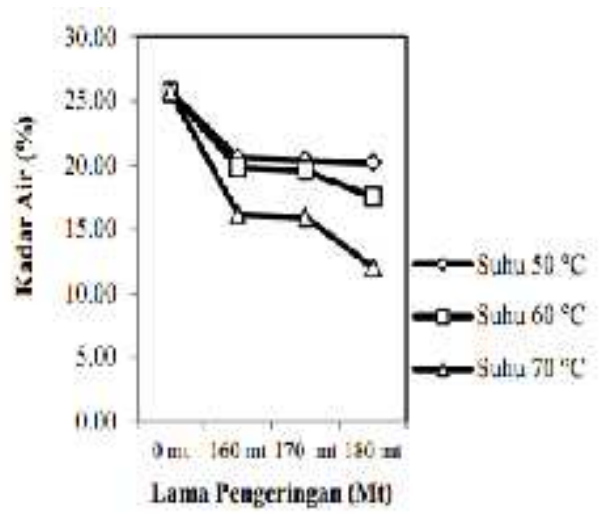

Gambar 4

Kadar air gabah sebelum dan sesudah pengeringan dengan menggunakan cabinet dryer

Hasil analisis perhitungan kadar air gabah menunjukkan bahwa perlakuan suhu dan lama pengeringan yang berbeda menghasilkan kadar air gabah yang berbeda pula. Kadar air tertinggi diperoleh dari perlakuan suhu 
$50^{\circ} \mathrm{C}$ dan lama pengeringan $160 \mathrm{mt}$ dengan rata-rata $20,56 \%$ sehingga dapat dihitung perubahan kadar air sebelum dan setelah pengeringan yaitu sebesar 5,10\%, sedangkan kadar air terendah adalah dari perlakuan suhu $70^{\circ} \mathrm{C}$ dan lama pengeringan $180 \mathrm{mt}$ dengan diperoleh rata-rata $12,03 \%$, sehingga dapat dihitung perubahan kadar air sebelum dan setelah pengeringan yaitu sebesar $13,63 \%$. Hal ini menunjukkan bahwa pemberian suhu yang rendah akan menyebabkan penurunan kadar air yang rendah pula demikian sebaliknya, karena dalam suatu proses pengeringan akan terjadi transfer suhu dari media pengering ke dalam bahan yang dimana semakin besar perbedaan suhu antara media dengan bahan maka semakin cepat pula perpindahan panas ke dalam bahan yang mengakibatkan cepatnya kadar air dalam bahan berkurang.

Berkurangnya kadar air dalam bahan akan berdampak pada udara sekitar bahan yakni dimana udara akan menjadi jenuh sehingga kemampuan untuk menyingkirkan uap air berkurang dengan demikian semakin lama proses pengeringan dilakukan maka penguapan kadar air gabah akan semakin menurun hingga konstan. Hal ini sesuai dengan pendapat (Siswantoro, dkk, 2012) yang menyatakan bahwa selama penggoengan panas yang ditransfer dari pasir ke dalam bahan (kerupuk) selain digunakan untuk menaikkan suhu kerupuk juga digunakan untuk penguapan air bahan. Dan pendapat (Abdul, 2012) yang menyatakan bahwa semakin besar perbedaan suhu antara medium pemanas dengan bahan pangan makin cepat pemindahan panas ke dalam bahan dan makin cepat pula penghilangan air dari bahan. Air yang keluar dari bahan yang dikeringkan akan menjenuhkan udara sehingga kemampuannya untuk menyingkirkan air berkurang sehingga dengan semakin tinggi suhu pengeringan maka proses pengeringan akan semakin cepat.

Persentase penguapan kadar air terbesar terjadi pada pengeringan gabah dengan menggunakan suhu $70^{\circ} \mathrm{C}$ selama $180 \mathrm{mt}$. Hal tersebut disebabkan karena suhu yang digunakan berbeda jauh dari suhu bahan yang mengakibatkan panas semakin cepat sampai ke permukaan bahan sehingga penguapan kadar air semakin cepat dan persentase kehilangan kadar air semakin besar. Pada tahap akhir proses pengeringan, peningkatan suhu gabah semakin konstan dan mendekati suhu udara panas karena kadar air di dalam bahan semakin berkurang sehingga penguapan kadar air semakin kecil.

Penurunan kadar air yang cukup besar diawal proses pengeringan karena pada tahap ini terjadi kontak panas dari udara panas ke permukaan bahan sehingga penguapan kadar air mula-mula terjadi di permukaan bahan yang berlangsung lebih cepat, dan pada tahap pengeringan selanjutnya penguapan kadar air terjadi di dalam bahan yang disebut sebagai penguapan lanjutan, pada tahap ini penguapan kadar air cenderung lambat karena 
jumlah kadar air di dalam bahan semakin berkurang sehingga penguapan kadar air menurun. Pada tahap akhir pengeringan penguapan kadar air semakin berkurang karena pada tahap ini terjadi proses pengeringan bahan dan suhu gabah cenderung konstan hingga mendekati suhu udara panas, proses ini akan terus berlanjut hingga kadar air yang tersisa di dalam bahan tidak dapat teruapkan lagi. Hasil ini sesuai dengan penelitian (Asensio, 1999 serta Yamsaengsung dkk, 2002a dalam Jamaluddin, dkk, 2009) yang menjelaskan bahwa perubahan bahan selama penggorengan disebabkan karena hilangnya air terikat dalam bahan. Pada awal penggorengan mula-mula air bebas di permukaan keluar dan beberapa lama air bebas dalam padatan juga keluar mengakibatkan padatan menjadi menyusut. Setelah semua air bebas keluar terjadi pengerasan di permukaan sehingga sebagian air bebas terjebak di dalam padatan. Dan pendapat (Abdul, 2012) yang menyatakan bahwa air bebas dapat dengan mudah diuapkan pada proses pengeringan. Bila air bebas ini diuapkan seluruhnya, maka kadar air bahan akan berkisar antara $12 \%$ sampai $25 \%$.

Dari hasil analisis perhitungan kadar air gabah dapat diketahui bahwa penurunan kadar air gabah dipengaruhi oleh suhu dan lama pengeringan. Dimana semakin tinggi suhu dan semakin lama waktu pengeringan maka kadar air gabah akan semakin menurun. Berdasarkan hasil yang diperoleh dari perubahan kadar air, maka dapat diketahui bahwa dengan menggunakan suhu yang rendah dan lama pengeringan yang singkat akan menghasilkan perubahan kadar air yang rendah, sedangkan dengan menggunakan suhu yang tinggi dan lama pegeringan yang lama akan menyebabkan perubahan kadar air yang tinggi. Hal ini sesuai dengan pendapat (Sri, dkk, 2013) yang menyatakan bahwa semakin tinggi suhu yang dihasilkan maka proses pengeringan akan lebih cepat serta pendapat (I Gusti dan Made, 2011) yang menyatakan bahwa Pengeringan adalah suatu proses pembuangan air yang terkandung pada suatu material yang dikeringkan. Pada proses pengeringan perlu adanya fluida udara kering yang mampu menyerap air di dalam material tersebut. Upaya yang dapat dilakukan untuk membuat udara kering adalah dengan melakukan pemanasan terhadap udara tersebut sebelum melintasi material yang dikeringkan. Dengan kondisi udara yang panas dan kering mampu menyerap air yang membasahi meterial tersebut sampai kering dalam waktu yang lebih singkat.

\section{Konduktivitas Panas}

Nilai konduktivitas panas gabah pada suhu dan lama pengeringan yang berbeda dapat dilihat pada tabel 1 . 
Tabel 1 konduktivitas panas gabah pada suhu dan lama pengeringan yang berbeda

\begin{tabular}{|c|c|c|c|}
\hline $\begin{array}{l}\text { waktu } \\
\text { (mt) }\end{array}$ & $\begin{array}{l}\text { kpada suhu } \\
50^{\circ} \mathrm{C}\left(W / m .{ }^{\circ} \mathrm{C}\right)\end{array}$ & $\begin{array}{c}\text { k pada } \\
\text { suhu } \\
60^{\circ} \mathrm{C} \\
\left(\mathrm{W} / \mathrm{m}^{\circ}{ }^{\circ} \mathrm{C}\right)\end{array}$ & $\begin{array}{l}\text { k pada suhu } \\
70^{\circ} \mathrm{C}\left(\mathrm{W} / \mathrm{m} .{ }^{\circ} \mathrm{C}\right)\end{array}$ \\
\hline 160 & 0,32 & 0,32 & 0,32 \\
\hline 170 & 0,32 & 0,32 & 0,32 \\
\hline 180 & 0,32 & 0,32 & 0,32 \\
\hline
\end{tabular}

laju pindah panas (q) melalui permukaan bahan dengan luas A jika pada benda tersebut diberikan panas dengan perbedaan suhu sebesar T1T2. Konduktivitas panas bahan erat kaitannya dengan porositas, struktur dan komposisi kimia, khususnya pada karakteristik udara, lemak dan air. Nilai konduktivitas panas sangat penting artinya dalam penyimpanan biji-bijian, proses pengolahan di pabrik, pendinginan dsb, khususnya menyangkut proses pindah panas secara konduksi (Nur, 2013).

Konduktivitas panas adalah suatu besaran intensif bahan yang menunjukkan kemampuannya untuk menghantarkan panas. (Falcon, 2008) menjelaskan bahwa konsep dasar konduktivitas panas adalah kecepatan dari proses difusi energi kinetik molekular pada suatu material yang menghantarkan panas. Walaupun mekanisme perambatan gerakan secara molekular pada perambatan panas hampir sama dengan perambatan dari suara dan sifat elektrik dari material itu, tetapi hanya ada sebagian dari hubungan secara teoritis yang bisa dicapai. konduktivitas termal merupakan kemampuan suatu benda dalam menghantarkan panas. Konduktivitas panas merupakan properti dari suatu material yang menentukan kemampuan suatu benda menghantarkan panas. Materi yang memiliki konduktivitas panas rendah dapat disebut dengan isolator yang baik.

Hasil analisis perhitungan konduktivitas panas gabah menunjukkan bahwa besar konduktivitas panas gabah tidak berbeda meskipun diberikan beberapa perlakuan suhu dan waktu yang berbeda dimana setiap perlakuan yang diberikan hasil yang didapatkan tetaplah sama yakni $0,32 \mathrm{~W} / \mathrm{m} .{ }^{\circ} \mathrm{C}$ nilai ini menunjukkan bahwa kecepatan panas mengalir dalam bahan (gabah) sebesar $0,32 \mathrm{~W} / \mathrm{m} .{ }^{\circ} \mathrm{C}$. Hal ini karena dalam penelitian yang telah dilakukan hanya menggunakan satu jenis bahan yakni gabah varietas ciherang dengan kadar airawal gabah diseragamkan sehingga besar konduktivitas panas gabah yang didapatkan tetaplah sama. Sebagaimana pendapat (Anton, dkk, tanpa tahun) yang menyatakan bahwa air mempunyai sifat konduktor, yang mampu merambatkan panas dengan baik. Semakin banyak air di dinding sel akan mempermudah perambatan panas di dalam kayu.

\section{Koefisien Pindah Panas}

Nilai koefisien pindah panas gabah pada suhu dan lama pengeringan yang berbeda dapat dilihat pada tabel 2 . 
Tabel 2 koefisien pindah panas gabah pada suhu dan lama pengeringan yang berbeda

\begin{tabular}{cccc}
\hline $\begin{array}{c}\text { Waktu } \\
\text { (mit) }\end{array}$ & $\begin{array}{c}\text { k pada suhu } \\
50^{\circ} \mathrm{C}\left(\mathrm{W} / \mathrm{m}^{2}, 0 \mathrm{C}\right)\end{array}$ & $\begin{array}{c}\text { k pada } \\
\text { suhu } \\
600^{\circ} \mathrm{C} \\
\left(\mathrm{W} / \mathrm{m}^{2}, 0 \mathrm{C}\right)\end{array}$ & $\begin{array}{c}\mathrm{kpada} \text { suhu } \\
70^{\circ} \mathrm{C}\left(\mathrm{W} / \mathrm{m}^{2}, 0 \mathrm{C}\right)\end{array}$ \\
\hline 160 & 31,77 & 31,77 & 31,77 \\
170 & 31,77 & 31,77 & 31,77 \\
180 & 31,77 & 31,77 & 31,77 \\
\hline
\end{tabular}

Koefisien pindah panas konveksi (h) merupakan besaran yang menyatakan tingkat kecepatan perpindahan kalor konveksi. Semakin tinggi nilai koefisien pindah panas konveksi maka perpindahan laju panas konveksi akan semakin tinggi sehingga penurunan kadar air bahan semakin cepat (Apriadi, dkk, 2011). Koefisien pindah panas pada dasarnya bukan merupakan sifat bahan pangan atau benda lain, yang digunakan untuk menghitung laju pindah panas konveksi dari/ke permukaan objek dan di perlukan untuk menghitung pindah panas pada proses pemanasan dan pendinginan.

Hasil analisis perhitungan koefisien pindah panas gabah pada setiap perlakuan yakni sebesar 31,77 $\mathrm{W} / \mathrm{m}^{2}{ }^{\circ} \mathrm{C}$. Hal ini karena besarnya nilai $\mathrm{h}$ lebih banyak dipengeruhi oleh kecepatan aliran udara panas. Sebagaimana pendapat (Siswantoro, dkk, 2012) yang menyatakan bahwa dari beberapa pustaka telah menyebutkan bahwa besarnya nilai $h$ tidak dipengaruhi oleh jenis dan ukuran bahan tetapi lebih banyak dipengaruhi oleh kecepatan media penghantar panasnya. Serta pendapat (Motawi, 1962 dalam Siswantoro, dkk, 2012) yang menyatakan bahwa besarnya nilai koefisien kontak panas permukaan (h) dengan udara sebagai media penghantar panas, dipengaruhi oleh kecepatan aliran udara disekitar obyek yang diuji.

\section{Keterbatasan Penelitian}

Dalam pelaksanaan penelitian ini, terdapat kekurangan yang diperoleh yaitu mesin pengeringan cabinet dryer yang digunakan harus dijaga dan diperhatikan suhunya karena suhu dapat berubah-ubah kapan saja dan tidak langsung secara konstan sehingga suhu dapat berpengaruh pada saat pengeringan gabah.

\section{KESIMPULAN}

Berdasarkan hasil pembahasan, maka dapat disimpulkan bahwa hasil penelitian menunjukkan bahwa nilai konduktivitas panas gabah dengan menggunakan persamaan dasar konduksi (hokum Fourier) sebesar 0,32 $\left(\mathrm{W} / \mathrm{m} .{ }^{\circ} \mathrm{C}\right)$ pada setiap perlakuan suhu dan waktu yang berbeda dan nilai koefisien pindah panas gabah dengan menggunakan persamaan dasar konveksi sebesar $31,77\left(\mathrm{~W} / \mathrm{m}^{2} .{ }^{\circ} \mathrm{C}\right)$ pada setiap perlakuan suhu dan waktu yang berbeda.

\section{DAFTAR PUSTAKA}

Abdul Rizal M, 2012. Pengeringan Temulawak dengan Heat Pump Drying Sederhana, (on line), 
(http://lib.ui.ac.id, 8 November 2016).

Anton Prasojo, Joko Sulistyo dan Tomy Listyanto, tanpa tahun. Konduktivitas Panas Empat Jenis Kayu dalam Kondisi Kadar Air yang Berbeda, (on line), (http://teknologihutan.fkt.ugm.ac.id , diakses 28 Maret 2017)

Anton Irawan, 2011. Modul Laboratorium Pengeringan. Jurusan Teknik Kimia Fakultas Teknik Universitas Sultan Ageng Tirtayasa, (on line), (http://che.ftuntirta.ac.id, diakses 18 April 2017).

Apriadi, Hanim Z.Amanah dan Nursigit Bintoro, 2011. Analisis Perpindahan Panas Dan Massa Proses Pengeringan Jagung Tongkol Pada Beberapa Metode Pengeringan Sederhana, (on line), (http://repository.ugm.ac.id, diakses 27 Maret).

Fadly Rian Arikundo dan Mulfi Hazwi, 2014. Rancang Bangun Prototype Kolektor Surya Tipe Plat Datar Untuk Penghasil Panas Pada Pengering Produk Pertanian Dan Perkebunan, Jurnal e-Dinamis, (on line), vol. 8, Nomor. 4, (http://jurnal.usu.ac.id, diakses 27 Maret 2016).

Falcon, Rafael. 2008. Analisis Karakteristik Termal, (on line), (http://www.lontar.ui.ac.id, diakses 1 Juli 2017).
I Gusti Agung Kade Suriadi dan Made Ricki Murti, 2011. Kesetimbangan Energi Termal Dan Efisiensi Transient Pengering Aliran Alami Memanfaatkan Kombinasi Dua Energi, Jurnal Teknik Industri, (on line), vol. 12, nomor. 1, (http://citation.itb.ac.id, diakses 27 Maret 2016).

Jamaluddin, Budi Rahardjo, Pudji Hastuti, dan Rochmadi, 2009. Rekayasa Pemekaran dan Tekstur Keripik Buah Nangka Selama Penggorengan Vakum. Jurnal Keteknikan Pertanian. Volume 23 (2). Halaman 125-132.

Manalu, Lamhot P, 2009. Menghitung Kebutuhan Pengering Gabah Di Kecamatan Ciomas Bogor Dengan Metode Monte Carlo, Jurnal Sains dan Teknologi Indonesia, (on line), vol. 11, nomor. 3, (http://ejurnal.bppt.go.id, diakses 27 Maret 206).

Nur Sakinah, 2013. Karakteristik Fisik da Termik. (on line). (http://sakinah20cluster.blogspot.c o.id, diakses 12 juli 2017).

Siswantoro, Budi Rahardjo, Nursigit Bintoro dan Pudji Hastuti. 2012. Pemodelan Matematik Pindah Panas dan Massa pada Penggorengan dengan Pasir Sebagai Media Penghantar Panas, Jurnal Agritech, (on line), vol. 32, nomor. 1. (http://journal.ugm.ac.id, diakses 18 April 2017). 
Sri Rezeky Meylani Nainggolan, Tamrin, Warji dan Budianto Lanya, 2013.

Uji Kinerja Alat Pengering Tipe Batch Skala Lab untuk Pengeringan Gabah dengan Menggunakan Bahan Bakar Sekam Padi, Jurnal Teknik Pertanian Lampung, (on line), vol. 2, nomor. 3, (http://repository.ac.id, diakses 11 April 2017).

Sumarni, 2010. Metode Pengeringan Makanan dan Fungsinya, (on line), (http:/leprints.undip.ac.id, diakses 2 Oktober 2016). 